Srđan Barišić

\title{
NATIO VS. CIVITAS ${ }^{1}$
}

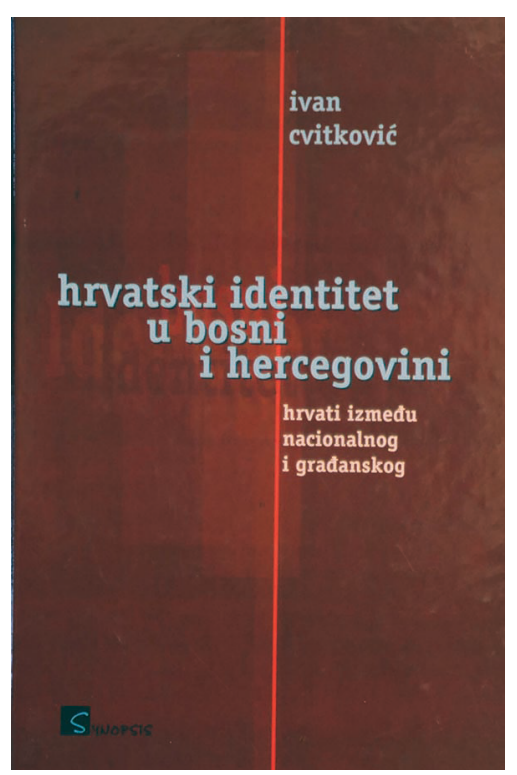

Dezintegracija bivše Jugoslavije praćena ratnim sukobima (1991-1995) ukazala je na svu kompleksnost nacionalnih odnosa u Bosni i Hercegovini. Kao izrazita multinacionalna sredina i granično područje, kako u nacionalnom, tako i u konfesionalnom pogledu, Bosna i Hercegovina, tačnije njeni stanovnici, podneli su najveću žrtvu raspada Jugoslavije. U poslednjoj deceniji XX veka broj stanovnika smanjen je za više od milion, a ratnim dejstvima uništena su, kako materijalna dobra i privreda Bosne i Hercegovine, tako i kulturna baština (spomenici kulture, džamije, katolički i pravoslavni hramovi).

Nakon prestanka ratnih sukoba, ustanovljena je nezavisna Bosna i Hercegovina, koja se sastoji iz dva entiteta (Federacija Bosne i Hercegovine i Republika Srpska) i distrikta Brčko, tj. specifično multinacionalno i multikonfesionalno društvo tri etniciteta - Bošnjaka, Hrvata i Srba. Problem uspostavljanja građanskog društva u novim etničkim okvirima i uspostavljanje dijaloga i tolerancije između (nedavno sukobljenih) nacionalnih identiteta predstavlja izazov za svakog sociologa koji se bavi međunacionalnim odnosima. Istraživanja nacionalne samoidentifikacije, etničkih predrasuda, socijalne (etničke) distance, stanja i perspektive međunacionalnih odnosa u društvu, mogu pružiti osnovu za prevazilaženje posledica identitetskih sukoba na prostoru bivše Jugoslavije i uspostavljanje stabilnog i dugoročnog mira i međunacionalne tolerancije.

Sociološka studija prof. Ivana Cvitkovića Hrvatski identitet u Bosni i Hercegovini: Hrvati između nacionalnog $i$ građanskog upravo predstavlja naučni doprinos uspostavljanju međunacionalne tolerancije i suživota na prostori-

\footnotetext{
${ }^{1}$ Prikaz knjige Hrvatski identitet u Bosni i Hercegovini. Sociologija, god. XLIX, br. 2, Beograd, 2007, str. 190-202.
} 
ma bivše Jugoslavije. Kao redovni profesor na predmetu Sociologija religije Fakulteta političkih nauka u Sarajevu i autor značajnih radova iz oblasti sociologije religije, prof. Ivan Cvitković bez sumnje predstavlja jednog od vodećih autoriteta iz pomenute oblasti u balkanskim naučnim krugovima. Pored brojnih radova iz oblasti opšte Sociologije religije kao što su Religije suvremenoga svijeta (1999), Sociologija religije (2004), Rječnik religijskih pojmova (2005), posebno bih izdvojio dve autorove studije Religije u Bosni i Hercegovini (1981) i Konfesija u Ratu (2004) koje su u uskoj vezi sa ovde prikazanom studijom Hrvatski identitet u Bosni i Hercegovini: Hrvati između nacionalnog $i$ građanskog (2006).

Primarno fokusirana na hrvatski identitet, ova sociološka analiza obuhvata sve tri nacije (Bošnjaci, Hrvati, Srbi), kao i celinu međunacionalnih odnosa u Bosni i Hercegovini. Reakcionarni karakter talasa buđenja nacionaliz(a) ma ranih devedesetih godina XX veka i istorijska i geografska isprepletanost identiteta onemogućavaju analizu samo jednog od njih bez analiziranja druga dva. Izrazito kritički odnos autora prema nacionalizmima u Bosni i Hercegovini možda je najvidljiviji u samom odgovoru na pitanje koje sam sebi unapred postavlja: Zašto samo o hrvatskom nacionalizmu i ekstremizmu, kao da ga nema kod Bošnjaka i Srba u Bosni i Hercegovini? "Da, ima. Ako hoćete moj stav o njima, onda u tekstu riječi 'hrvatski nacionalizam' zamijenite riječima 'bošnjački nacionalizam' ili ‘srpski nacionalizam' i dobit ćete odgovor na to pitanje." (str. 297)

Analizom "stanja nacija i nacionalne svesti" u Bosni i Hercegovini pred rat (1991-1995), autor objašnjava proces nacionalne homogenizacije, koji je primetan već krajem osamdesetih godina. Opšta društvena kriza uslovljava krizu identiteta, a u uslovima ugroženosti čovek se okreće nacionalnom i religijskom (konfesionalnom) identitetu kao nečemu što će ga očuvati u zajednici. Težnja ka homogenizaciji jača u uslovima ugroženosti. "Homogenizacija se vršila na egoizmu, jačanju vlastitog na račun rušenja tuđeg (kulturnih, vjerskih, gospodarskih i drugih obilježja). Homogenizacija je dovela do toga da su ljudi živjeli u čistoj formi kao Hrvati, Srbi, Muslimani; živjeli su samo u naciji i konfesiji." (str. 48) Diferencijacija društva, prvenstveno zasnovana na nacionalnim razlikama, nužno je vodila konfliktima, antagonizmu interesa nacionalnih grupa, a konflikti su, opet, povećavali nacionalnu homogenizaciju. Nacionalno organizovanje bilo je pokušaj traženja sigurnosti u kolektivu i već početkom 1989. godine pojavljuju se populistički etničko-nacionalnokonfesionalni projekti proklamovani od strane nacionalnih (nacionalističkih) stranaka. Već nakon prvih višestranačkih izbora u Bosni i Hercegovini, željeni politički pluralizam pretvorio se u etničko trostranačje (SDA, SDS, HDZ) 
i "nacionalni kolektivizam doveo je gotovo do refeudalizacije bosansko-hercegovačkog društva. Premještanje od osobnog k nacionalnom dovelo je do strahovitog podaništva nacionalnoj oligarhiji. Vlast se etnički teritorijalizirala (općine s hrvatskom, muslimanskom ili srpskom vlašću).” (str. 51) Zaustavljeni su svi (tek započeti) demokratski procesi i na političku scenu stupaju nacionalizmi i šovinizmi.

Nacionalna homogenizacija i integracija vodila je sa jedne strane unutrašnjoj integraciji, a sa druge strane spoljašnjoj dezintegraciji. Pored socijalnih konflikata, autor smatra da u uzroke nacionalnih sukoba treba svrstati i "indoktriniranost ovdašnjih naroda stvarnom ili irealnom ugroženošću”. Monopolizacija žrtve, mitologizacija i glorifikacija nacionalne istorije i sakralizacija politike i istorije, zajedničke su karakteristike sva tri identiteta.

Religija i konfesija imaju važnu ulogu u kolektivnom identititetu balkanskih naroda te bi se moglo reći da je, istorijski gledano, kod Srba, Hrvata i Bošnjaka u Bosni i Hercegovini snažnija konfesionalna od nacionalne svesti. Autor postavlja pitanje: Je li nacija sredstvo konfesije, ili konfesija sredstvo nacije, tj. koji je identitet primarniji? Kada je reč o hrvatskom identitetu u Bosni i Hercegovini, značajna je uloga franjevaca koji su, u vreme dugovekovne uprave Osmanskog, a zatim Austro-Ugarskog Carstva, uticali na buđenje i očuvanje (najpre) konfesionalnog, ali i nacionalnog identiteta. Nisu li oni u velikoj meri zaslužni za izgradnju kolektivne svesti i svesti o pripadnosti Hrvata u Bosni i Hercegovini. Nije li slična uloga Srpske pravoslavne crkve u očuvanju srpskog nacionalnog identiteta? Međutim, kada "drugi”, sa kojim ste u političkom i socijalnom sukobu, ima i drugu religiju, ili konfesiju, konflikt lako biva nadograđen verskim sukobom. "Sakralizacija nacionalnog identiteta dovela je do apsurda da se i rušenje (tuđeg) hrama pretvara u čin 'pobožnosti', čin 'borbe za vjeru'." (str. 229) Pored konfesionalne različitosti, bosansko-hercegovački nacionalizmi (bošnjački, hrvatski i srpski), svoje uporište pokušavali su (i uspevali) da nađu i u problemima jezika.

Tokom rata na tlu Bosne i Hercegovine tri nacionalne stranke formirale su tri nacionalna "aparata vlasti" (Republika Srpska, HR "Herceg-Bosna" i "Vlada BiH" - vlada sa dominantnom upravom SDA), čime su nacionalističke ideologije novoformiranih političkih elita ozvaničene kao "legitimni" predstavnici i jedini "pravi i istinski” zastupnici nacionalnih (nacionalističkih) interesa. Analizirajući ulogu političkih "zastupnika nacionalnih interesa", njihovih aspiracija, pregovora i dogovora, autor uspeva da ukaže na svu kompleksnost različitih oblika nacionalne identifikacije koja je postojala kod pripadnika sva tri identiteta. Rat svih protiv svih i opšta konfuzija koja je zavladala u Bosni i Hercegovini, uvukla je u nacionalistički vrtlog sve druš- 
tvene slojeve i institucije. Bošnjački unitarni koncept, velikosrpstvo i velikohrvatstvo, sudarili su se u svoj svojoj silini, rušeći sve građansko i ljudsko na prostoru Bosne i Hercegovine. Ova sociološka analiza strašnog sudara bosansko-hercegovačkih nacionalizama upravo je inspirisana težnjom da se obnovi i podigne na noge (sudarom smrvljeni) građanski identitet.

Nakon rata, stvorena je nezavisna Bosna i Hercegovina, zajednička država Bošnjaka, Hrvata i Srba. Novonastala država "treba biti sredstvo koje će omogućiti narodima u Bosni i Hercegovini da žive 'na svoj način', u svojoj različitosti, a ne da ih ukida." (str. 111) Autor u nekoliko navrata ističe da osnova (novog) državnog identiteta Bosne i Hercegovine ne može biti ni jezik, ni istorija, ni religija, ni konfesija, već pravo na državljanstvo (pravo na građanstvo) koje će biti osnova društva. Državni identitet Bosne i Hercegovine treba da se zasniva na potpunoj nacionalnoj i konfesionalnoj ravnopravnosti i maksimalnom uvažavanju i prihvatanju tradicija i kulturnih različitosti građana. Isticanjem značaja državnog identiteta autor ističe interese svih građana, bez obzira na njihovu nacionalnu ili konfesionalnu pripadnost. Državni i nacionalni identitet nisu i ne trebaju biti sukobljeni, već trebaju uvažavati jedan drugog, kako bi svim građanima, ali i svim nacionalnim zajednicama, bilo bolje. Autorovo zalaganje za reintegraciju Bosne i Hercegovine ne podrazumeva ukidanje nacionalnih identiteta, već naprotiv, njihovo očuvanje. "Bosna i Hercegovina treba se razvijati tako da u njoj jača politički identitet (osnovan na 'demosu') više nego kulturni identitet (osnovan na 'etnosu')..." Kao primer i uzor za reintegraciju bosansko-hercegovačkog društva autor predlaže evropski identitet koji ničim ne ugrožava nacionalni identitet onih koji su ušli u Evropsku uniju.

Međutim, postavlja se pitanje šta je potrebno učiniti kako bi se reintegrisala građanska svest u Bosni i Hercegovini? Prevladavanje prošlosti nužan je uslov za uspostavljanje međunacionalne tolerancije: "O onom lošem, posebno o zločinu, treba govoriti i pisati ne ni hrvatskim, ne ni srpskim, ne ni bosanskim, nego jezikom savjesti. A ona nalaže stid." (str. 75) To naravno podrazumeva demonopolizaciju istine, preispitivanje odgovornosti i napuštanje retorike žrtve: "Previše je oplakivanja svoje nevinosti u ovdašnjoj literaturi o događajima u naciji na prijelazu iz XX u XXI stoljeće. 'Mi' smo pravednici, 'Mi' smo napadnuti, vodili smo odbrambeni rat i nismo mogli počiniti zločin. (...) Sve je to glazba 'pravednika' koja se mogla čuti i na druge 'dvije strane'. A Nitko neće priznati odgovornost zbog svoje šutnje, neprotivljenja zločinu, zbog svojeg odnosa prema lažnom interesu nacije, jer 'nismo bili obaviješteni', 'nismo znali'.” (str. 75) Razvoj samokritične svesti koja će biti spremna da snosi odgovornost i prizna krivicu, suočavanje sa sopstvenim predrasuda- 
ma i otvoren i iskren pristup, nužne su pretpostavke uspostavljanja međunacionalne i interkonfesionalne tolerancije i nužan uslov za razvoj građanske svesti. Naravno, ravnopravnost kako individualnih, tako i kolektivnih identiteta nikako ne sme biti dovedena u pitanje: "Kad bude jednakost u distribuciji moći i u ljudskim pravima na cijelom teritoriju Bosne i Hercegovine između Bošnjaka, Hrvata i Srba - tad će vjerojatno nestati nacionalne napetosti.” (str. 292) 